\title{
RESEARCH PAPER \\ Simulation of control strategies for decision-making regarding Digitaria sanguinalis in glyphosate-resistant soybeans
}

\author{
Fernando H. Oreja ${ }^{1}$, Fernando Bastida ${ }^{2}$, and José L. Gonzalez-Andújar ${ }^{3}$ \\ ${ }^{1}$ Department of Plant Production, Faculty of Agronomy, University of Buenos Aires, Avenida San Martín \\ 4453, (1417) Buenos Aires, Argentina. \\ ${ }^{2}$ Departamento de Ciencias Agroforestales, Universidad de Huelva, Campus de La Rábida, Carretera Palos \\ de La Frontera s/n, 21819 Palos de La Frontera, Huelva, Spain. ${ }^{3}$ Instituto de Agricultura Sostenible (CSIC), \\ Alameda del Obispo, Aptdo. 4080, (14080). Cordoba, Spain.
}

\begin{abstract}
F.H. Oreja, F. Bastida, and J.L. Gonzalez-Andújar. 2012. Simulation of control strategies for decision-making regarding Digitaria sanguinalis in glyphosate-resistant soybeans. Cien. Inv. Agr. 39(2): 299-308. A bioeconomic model was developed for decision-making regarding large crabgrass (Digitaria sanguinalis) control in glyphosate-resistant soybeans in the Rolling Pampas of Argentina. The model was used to evaluate the economic returns of four different glyphosate-based strategies for weed control. In the absence of herbicide application (T1), the soil seed bank increases to an equilibrium density of 12,079 seeds $\mathrm{m}^{-2}$ in three years. A single herbicide application during the early stages of the crop (T2), which was intended to be highly effective in the control of an early weed cohort, allows a late, unaffected cohort to produce sufficient seeds to maintain population densities in the soil seed bank. A single, delayed herbicide application (T3), which was intended to control both early and late cohorts, results in a soil seed bank increase up to an equilibrium density similar to that achieved without treatment. Two sequential herbicide applications per year (T4), targeting the two cohorts, leads to a soil seed bank density after 10 years of 107 seeds $\mathrm{m}^{-2}$. Model predictions indicate that in the absence of control measures, a 93\% reduction in soybean yield was predicted due to weed interference. The lowest reduction in crop yield (27\%) was predicted using strategy T4, which is the most common control measure used by local farmers. This strategy clearly outperforms the other options tested, leading to lower $D$. sanguinalis seed bank densities and higher soybean yields and economic returns compared to those obtained using the alternative strategies.
\end{abstract}

Key words: Crop-weed competition, Digitaria, herbicides, Glycine max, large crabgrass, sensitivity analysis, transgenic crop.

\section{Introduction}

Digitaria sanguinalis (L.) Scop. (large crabgrass) is a common summer annual weed that grows in

Received May 5, 2011. Accepted June 25, 2012.

Corresponding author: andujar@cica.es both temperate and tropical regions (Holm et al., 1977 ) and is a serious problem in many row crops (Mohler and Callaway, 1995; Monks and Schultheis, 1998; Bhowmik et al., 1999; Sarker et al., 2002; Aguyoh and Masiunas, 2003; Fu and Ashley, 2006) and in turf grasses (Walker et al., 1998; Richmond et al., 2003). In Argentina, this weed is considered 
one of the ten most important weeds (Mitidieri, 1989), especially for the main Rolling Pampas crops (Mitidieri, 1989; Suárez et al., 2001; de la Fuente et al., 2006). In particular, large crabgrass has become an important weed in soybean (Glycine max (L.) Merr.) (Marzocca, 1994; James, 2001). The seeds of this weed follow the typical dormancy pattern exhibited by most summer weeds in temperate climates. First, a period of deep dormancy occurs after dispersion in autumn (Gallart et al., 2008), then it is broken by cold temperatures during the winter (Toole and Toole, 1941; Delouche, 1956) and finally warm spring temperatures trigger germination and emergence (Masin et al., 2006). A high percentage of germination is generally achieved by alternating temperatures $\left(20^{\circ} / 30^{\circ} \mathrm{C}\right.$, $20^{\circ} / 35^{\circ} \mathrm{C}, 20^{\circ} / 40^{\circ} \mathrm{C}(18 \mathrm{~h} / 6 \mathrm{~h})$ ) (Toole and Toole, $1941)$ or constant warm temperatures $\left(25^{\circ} \mathrm{C}, 30\right.$ ${ }^{\circ} \mathrm{C}$ ) (King and Oliver, 1994). The viability of $D$. sanguinalis seeds varies from 25\% (Burnside et al., 1996; Rahman et al., 2001) to 12\% (Egley and Chandler, 1978) for 1 to 2.5 years after dispersion, respectively, when seeds remain at a 6 -cm depth in the soil. In contrast, seed viability at the soil surface decreases due to exposure to extreme temperatures (Forcella et al., 2000), desiccation (Buhler, 1995) or predation (Menalled et al., 2000).

Chemical control, especially using glyphosate [ $N$-(phosphonomethyl) glycine], is mainly used to control weeds under no-tillage systems in which glyphosate-tolerant (RoundupReady ${ }^{\circledR}$ ) soybeans are grown. This herbicide provides approximately $98 \%$ control of D. sanguinalis (Culpepper et al., 2001; Van Gessel et al., 2001; Norsworthy, 2004). Despite such effective control, researchers have found that D. sanguinalis populations have remained stable or even increased in no-tillage systems, especially in maize-soybean rotations (Zanin et al., 1997; Tuesca et al., 2001; Davis et al., 2005; Puricelli and Tuesca, 2005). This weed shows high fecundity and has two main cohorts during the crop cycle (Oreja and de la Fuente, 2005); both of these traits facilitate the long-term survival of this weed.
Weed management decision-making is a complex task requiring the integration of many biological, agronomic and economic factors. Growers and consultants can manage the integration of these factors using Decision Support Systems (DSS) (Gonzalez-Andujar et al., 2010). DSS can provide a structure upon which farmers can base their decisions and offer hypotheses for tackling weed management problems. A bioeconomic model can be used as a component of DSS. The use of bioeconomic models is a useful technique that integrates biological, agronomic and economic knowledge, thereby producing a framework that can be used to evaluate the economic performance provided by various management scenarios (Gonzalez-Andujar and Fernandez-Quintanilla, 1993; Swinton and King, 1994; Gonzalez-Andujar et al., 2010).

The objective of this study was to develop a bioeconomic model for $D$. sanguinalis control decision-making in glyphosate-resistant soybeans and to use this model to evaluate the economic returns of various herbicide-based management strategies for the Rolling Pampas of Argentina.

\section{Materials and methods}

The model integrates three sub-models: life cycle, competition with the crop and an economic sub-model.

\section{Life-cycle sub-model}

The sub-model used is based upon life-cycle models described by various authors (GonzalezAndujar and Fernandez-Quintanilla, 1993; Torra et al., 2008; Gonzalez-Diaz et al., 2009) but has been extended to consider two weed seedling cohorts: an early cohort that emerges in late November and a late cohort that emerges at the end of December. 
Seedling emergence. The number of seedlings $\left(P\right.$, seedlings $\left.\mathrm{m}^{-2}\right)$ emerging in year $t$ for each cohort $(i)$ is given by:

$$
P_{t, i}=S B_{t, i} e_{i} \quad(\mathrm{i}=1,2)
$$

where $e$ is the proportion of seedlings emerging from the seed bank $(S B)$ in year $t$ for each cohort $(\mathrm{i}=1,2)$.

However, glyphosate application reduces the number of recruits by destroying some of the emergent seedlings. If $c$ represents the proportion of $D$. sanguinalis individuals that are killed by the herbicide, equation (1) becomes:

$$
P_{t, i}=\left(1-c_{i}\right) S B_{t, i} e_{i} \quad(\mathrm{i}=1,2)
$$

Seedling survival. The number of seedlings that survive to the adult stage $\left(A\right.$, adult plants $\left.\mathrm{m}^{-2}\right)$ in year $t$ was modeled using the following densitydependent, hyperbolic relationship:

$$
A_{t, i}=P_{t, i} /\left(1+a_{i} P_{t, i}\right) \quad(\mathrm{i}=1,2)
$$

where $a_{i}$ is the reciprocal of the asymptotic value of $A$ for cohort $i$.

Seed production. An increase in the density of adult plants implies a reduction in plant fecundity $\left(F\right.$, seeds plant $\left.{ }^{-1}\right)$ due to the density-dependent nature of the response. The process can be modeled using the following hyperbolic model:

$$
F_{t, i}=f_{i} /\left(1+b_{i} A_{t, i}\right) \quad(\mathrm{i}=1,2)
$$

where $f$ is the fecundity (seeds plant ${ }^{-1}$ ) of an isolated plant and $b$ is a parameter related to the strength of the density-dependence of fecundity.

Total seed production. The total seed production $\left(S\right.$, seeds $\left.\mathrm{m}^{-2}\right)$ is given by

$S_{t}=\sum F_{t, i} A_{t, i} \quad(\mathrm{i}=1.2)$

Seed losses. Nevertheless, not all of the seeds produced in a year are incorporated into the soil seed bank because some can be lost to predators or removed with the harvest. Therefore, the total number of seeds reaching the seed bank $\left(L\right.$, seeds $\left.\mathrm{m}^{-2}\right)$ in year $t$ is given by the following equation:

$L_{t}=S_{t}(1-p)$

where $p$ represents the proportion of seeds lost.

Seed bank. The size of the seed bank for a given year $\left(S B\right.$, seeds $\left.\mathrm{m}^{-2}\right)$ is the sum of seeds surviving in the soil from the previous year and the seeds added during the current year. Thus, the final size of the seed bank in year $t+1$ is given by:

$$
B S_{t+1}=B S_{t}\left(1-e_{1}\right)\left(1-e_{2}\right)(1-m)+L_{t}
$$

where $m$ is the proportional mortality of the seed bank in one year.

\section{Competition sub-model}

The relationship between the total number of adult weed plants ( $A T$, plants $\mathrm{m}^{-2}$ ) and crop yield $\left(\mathrm{Y}_{t}, \mathrm{~kg} \mathrm{ha}^{-1}\right)$ has been modeled using the following equation (Oreja and Gonzalez-Andujar, 2007):

$Y_{t}=Y \exp \left(-b A T_{t}\right)$

where $A T=\sum A_{i}(\mathrm{i}=1,2), Y$ is the maximum crop yield in the absence of weed plants and $b$ is a parameter that represents the yield lost by competition between the crop and the weeds.

\section{Economic sub-model}

The economic component of the model describes the impact of alternative weed management strategies on profit.

$N R_{t}=\left(P_{t}^{*} R_{t}\right)-F C-H C$

where $N R$ is the net return (US\$ ha-1), $P$ is the price of soybean $\left(\mathrm{US} \$ \mathrm{t}^{-1}\right), F C\left(\mathrm{US} \$ \mathrm{ha}^{-1}\right)$ are the 
fixed costs (tillage, seeds, fertilizer, etc.) and $H C$ $\left(\mathrm{US} \$ \mathrm{ha}^{-1}\right)$ is the herbicide treatment cost.

The variation in expected returns with time over an extended period is given by the annualized net return $\left(A N R\right.$, US $\$$ ha $^{-1}$ year $\left.^{-1}\right)$ and is expressed as,

$$
\mathrm{ANR}=\left(\sum_{t=1}^{n}\left[\mathrm{NR}_{t} \cdot(1+i)^{-t}\right]\right) \cdot \frac{i}{1-(1+i)^{-n}}
$$

where $i$ is the inflation rate (a value of 5\% was used in the analysis).

\section{Model parameters and initial conditions}

The demographic parameter values used in the model were obtained from the literature (Hiroyuki and Atsushi, 2005; Oreja and de la Fuente, 2005). A summary of the values used in the model parameterization is shown in Table 1.

The effectiveness of the control of $D$. sanguinalis using glyphosate was obtained from Norsworthy (2004), and the competitive effects of the weed on crop yield were obtained from Oreja and Gonzalez-Andujar (2007).

In the economic sub-model, the estimated total fixed costs $(F C)$ and herbicide treatment costs $(H C)$

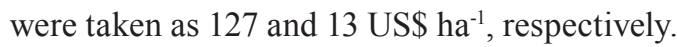

For simulation purposes, an initial seed bank population of 100 seeds $\mathrm{m}^{-2}$ was considered. The model runs were carried out over 10 years, a time that is sufficiently long to assume that equilibrium density has been reached (Gonzalez-Andujar and Fernandez-Quintanilla, 1993).

\section{Simulated weed management strategies}

We considered the following herbicide-based management strategies:

a) Strategy T1: No glyphosate application. This strategy may be considered as a control because it involves no specific measure to manage large crabgrass.

b) Strategy T2: A single herbicide application during the early stages of the crop. This strategy implies $100 \%$ control of the early cohort (Norsworthy, 2004) and no control of the late cohort.

c) Strategy T3: A single, delayed herbicide application. Glyphosate is applied later, at stage R1 of the crop (Fehr and Caviness, 1977), leading to $75 \%$ control of the early cohort and $67 \%$ control of the late cohort.

d) Strategy T4: Two sequential applications of glyphosate per year, resulting in 98\% control of the early cohort and $100 \%$ control of the late cohort (Culpepper et al., 2001).

Table 1. Model parameter values.

\begin{tabular}{lcc}
\hline Parameter & & Value \\
\hline Life-cycle submodel & & \\
Emergence, early cohort & $\mathrm{e} 1$ & 0.29 \\
Emergence, late cohort & $\mathrm{e} 2$ & 0.14 \\
Survival parameter, early cohort & $\mathrm{a} 1$ & 0.003 \\
Survival parameter, late cohort & $\mathrm{a} 2$ & 0.20 \\
Fecundity, early cohort & $\mathrm{f} 1$ & 5,056 seeds plant $^{-1}$ \\
Fecundity, late cohort & $\mathrm{f} 2$ & $100 \quad$ seeds plant \\
Seed loss from the seed bank & $\mathrm{p}$ & 0,73 \\
Seed mortality in soil & $\mathrm{m}$ & 0,46 \\
Competence sub-model & & \\
Potential soybean yield & $\mathrm{Y}$ & $3,157 \mathrm{~kg} \mathrm{ha}^{-1}$ \\
Parameter & $\mathrm{b}$ & 0.40 \\
Economic sub-model & & \\
Soybean price & $\mathrm{P}$ & $124 \mathrm{US} \mathrm{ton}^{-1}$ \\
Herbicide cost & $\mathrm{HC}$ & $13{\mathrm{US} \$ \mathrm{ha}^{-1}}^{-1}$ \\
Fixed costs & $\mathrm{FC}$ & $127 \mathrm{US} \mathrm{ha}^{-1}$ \\
Inflation rate & $\mathrm{i}$ & $5 \%$ \\
\hline
\end{tabular}




\section{Sensitivity analysis}

In the model described here, all parameters were assumed constant; however, in practice, most parameters vary due to spatial and temporal variability in the abiotic environment. A sensitivity analysis was performed to assess the sensitivity of the ANR (Annualized Net Return) to variation in the model parameters. The sensitivity coefficient is expressed mathematically (Gonzalez-Andujar and Fernandez-Quintanilla, 1991) as the absolute value of the following:

$S=(\Delta O / O) /(\Delta p / p)$

where $p$ is the standard value of the parameter being analyzed, $\Delta p$ is the change in the parameter value and $O$ represents the model output. The sensitivity index $(S)$ is a measure of the relative change in model output resulting from a relative change in a given parameter value.

Parameters were modified by $\pm 40 \%$ (Table 2), and fluctuating original values of the parameters were considered before the model was run (Table 1). This variation was considered adequate to represent the possible parameter variations under real conditions following Gonzalez-Andujar and Fernandez-Quintanilla (1991).

\section{Results and discussion}

In the absence of control measures (strategy T1), the large crabgrass soil seed bank is projected to rise from 100 seeds $\mathrm{m}^{-2}$ to an equilibrium population of 12,079 seeds $\mathrm{m}^{-2}$ in three years (Figure 1). This high density can be considered the carrying capacity of $D$. sanguinalis in association with soybean under the specified conditions. The resulting large populations of the weed are expected to cause substantial yield losses (Figure 2).

Strategy T2, which represents the most common management strategy used by farmers, failed to control $D$. sanguinalis, leading to a final equilibrium population in the soil of 9,280 seeds $\mathrm{m}^{-2}$ (Figure 1). The late, uncontrolled cohort produces enough seeds to replenish the seed bank, thus increasing infestation levels to only $23.17 \%$ below the carrying capacity of $D$. sanguinalis in the crop system.

A delay in herbicide treatment intended to control both the early and late cohorts with a single glyphosate application (Strategy T3) has been suggested as an alternative management strategy for D. sanguinalis (Oreja and de la Fuente, 2005). However, the predicted equilibrium population density after 10 years is 11,078 seeds $\mathrm{m}^{-2}$ (Figure

Table 2. Sensitivity analysis.

\begin{tabular}{|c|c|c|c|c|c|c|c|c|}
\hline \multirow[b]{2}{*}{ Parameters } & \multicolumn{2}{|c|}{ Strategy T1 } & \multicolumn{2}{|c|}{ Strategy T2 } & \multicolumn{2}{|c|}{ Strategy T3 } & \multicolumn{2}{|c|}{ Strategy T4 } \\
\hline & $+40 \%$ & $-40 \%$ & $+40 \%$ & $-40 \%$ & $+40 \%$ & $-40 \%$ & $+40 \%$ & $-40 \%$ \\
\hline \multicolumn{9}{|l|}{ Biological parameters } \\
\hline Emergence, early cohort & -0.19 & 0.22 & 0.15 & 0.12 & 0.22 & 0.19 & 0.22 & 0.21 \\
\hline Emergence, late cohort & -0.07 & 0.09 & 0.02 & 0.01 & 0.01 & 0.01 & 0.03 & 0.03 \\
\hline Survival parameter, early cohort & -0.30 & 0.39 & 0.34 & 0.33 & 0.45 & 0.45 & 0.36 & 0.36 \\
\hline Survival parameter, late cohort & -0.01 & 0.01 & 0.01 & 0.01 & 0.03 & 0.03 & 0.01 & 0.01 \\
\hline Fecundity, early cohort & 0.99 & -0.99 & 0.85 & 0.85 & 0.68 & 0.68 & 0.78 & 0.78 \\
\hline Fecundity, late cohort & 0.01 & -0.01 & 0.02 & 0.01 & 0.01 & 0.02 & 0.03 & 0.02 \\
\hline Seed loss from the seed bank & -2.64 & 2.69 & 1.81 & 1.81 & 1.96 & 1.96 & 1.88 & 1.88 \\
\hline Seed mortality in soil & -0.35 & 0.48 & 0.43 & 0.44 & 0.22 & 0.22 & 0.28 & 0.28 \\
\hline Soybean yield & 4.50 & 4.50 & 3.47 & 3.48 & 4.16 & 4.16 & 2.10 & 2.10 \\
\hline \multicolumn{9}{|l|}{ Economic parameters } \\
\hline Soybean Price & 0.24 & 0.24 & 0.18 & 0.17 & 0.38 & 0.38 & 0.45 & 0.45 \\
\hline Herbicide costs & --- & ---- & 0.12 & 0.12 & 0.18 & 0.18 & 0.23 & 0.23 \\
\hline Fixed costs & 1.13 & -1.13 & 1.01 & 1.02 & 0.87 & 0.87 & 0.99 & 0.99 \\
\hline
\end{tabular}




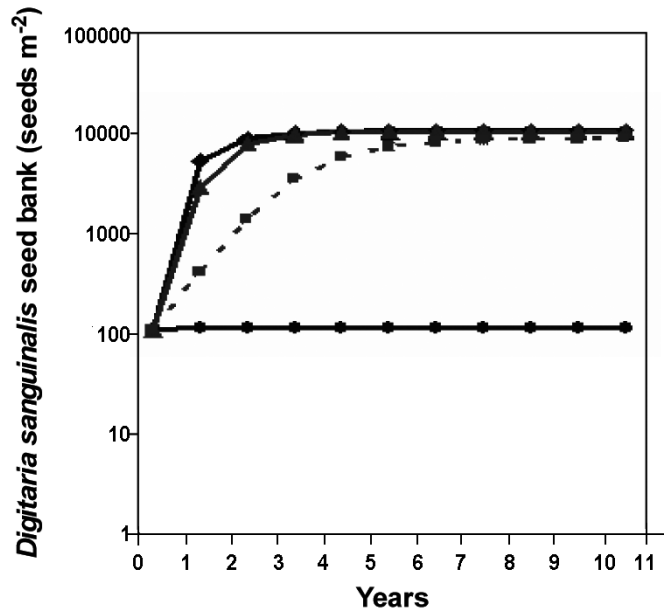

Figure 1. Evolution of the soil seed bank of Digitaria sanguinalis under various control strategies that differentially affect the early and late seedling cohorts of the weed in soybeans. Strategy T1 ( $\bullet$ : no control. Strategy T2 (Ш): $100 \%$ and $0 \%$ control of the early and late cohorts, respectively. Strategy T3 (४): 75\% and 67\% control of the early and late cohorts, respectively. Strategy T4(•): 98\% and $100 \%$ control of the early and late cohorts, respectively.

1). This practice causes a large increase in the seed bank because it is not able to adequately control both cohorts.

Strategy T4 aims to control both cohorts with two sequential glyphosate applications per year. Nevertheless, an increase in the soil seed bank up to an equilibrium density of 107 seeds $\mathrm{m}^{-2}$ is predicted using this strategy (Figure 1).

Thus, our results indicate that the different management strategies tested for the study crop are not effective in reducing the $D$. sanguinalis soil seed bank.

In simulations, a weed-free soybean yield of $3,157 \mathrm{~kg} \mathrm{ha}^{-1}$ was used (Oreja and de la Fuente, 2005). Predictions based on strategy T1 indicated that the large populations of large crabgrass that developed in the absence of herbicide treatment may result in a $93 \%$ reduction in potential yield (220 $\mathrm{kg} \mathrm{ha}^{-1}$, Figure 2). The predicted yield using strategy T2 was $793 \mathrm{~kg} \mathrm{ha}^{-1}$, representing a $75 \%$ loss in yield (Figure 2). Delaying the single glyphosate application to attempt to control both cohorts (strategy T3) leads to a predicted yield of $236 \mathrm{~kg} \mathrm{ha}^{-1}$ (Figure 2), i.e., a 92\% reduction in the soybean potential yield. This result confirms the finding of Leguizamón (1976) that a delay in controlling weeds in soybean causes serious yield losses. The highest yield (2,298 kg ha $^{-1}$ ) was predicted using strategy T4 (Figure 2). However, this predicted yield is $27 \%$ lower than the potential yield.

The highest annualized net return (145 US\$ ha-1) was obtained using strategy T4 (Figure 3). Strategy T2 also produced a positive $A N R$, although this value was considerably lower than the $A N R$ obtained using strategy T4 (23 US\$ ha ${ }^{-1}$, Figure 3). Strategies $\mathrm{T} 1$ and $\mathrm{T} 3$ resulted in negative $R N A$ values (Figure 3). Clearly, the viability of these weed control strategies is questionable.

The simulation results confirmed the difficulty of controlling large crabgrass in soybean using the common management practice in Argentina, i.e., strategy T2. Despite the high efficacy achieved by the herbicide, the fact that the treatment affects only the first cohort renders it ineffective in reducing the D. sanguinalis soil seed bank. All of the alternative control practices tested in this study were also insufficient to reduce $D$. sanguinalis populations. The minimum efficacy required to effectively control $D$. sanguinalis populations is at least $99 \%$ for each cohort. Apparently, treatments have to be very effective and consistent in order to manage $D$. sanguinalis. For other weed species, such as Agrostemma githago L., Striga hermonthica (Delile) Benth., Avena sterilis L. or Alopecurus myosuroides Huds., the estimated reductions, according to the efficacy of weed control, required to maintain the population at equilibrium ranged from $90 \%$ to $95 \%$ (Cousens and Mortimer, 1995). Nevertheless, it would be necessary to consider other practices to manage this weed as a part of an integrated weed management, such as the use of crop rotation, altered sowing dates or crop structure. (Fernandez-Quintanilla et al., 1987).

Annualized net return was particularly sensitive to changes in weed seed losses, fixed costs and crop 


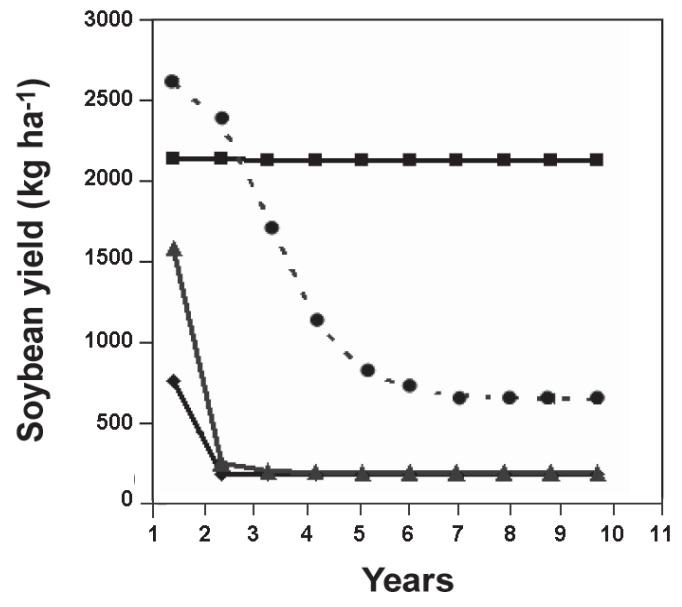

Figure 2. Evolution of soybean yields under various Digitaria sanguinalis control strategies. Strategy T1 ( $\bullet$ : no control. Strategy T2 (•): $100 \%$ and $0 \%$ control of the early and late cohorts, respectively. Strategy T3 (ム): 75\% and $67 \%$ control of the early and late cohorts, respectively. Strategy T4(-): $98 \%$ and $100 \%$ control of the early and late cohorts, respectively.

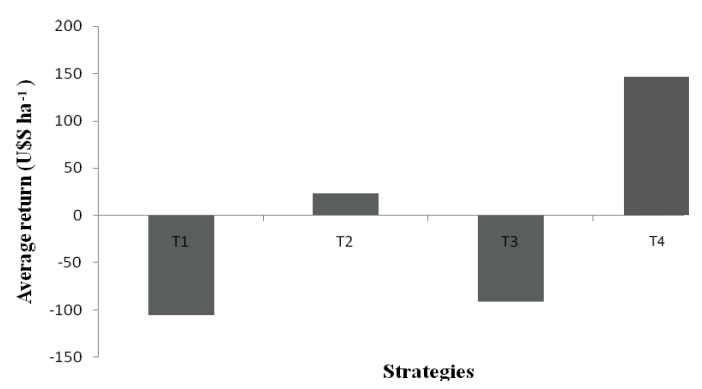

Figure 3. Average net returns under various Digitaria sanguinalis control strategies. Strategy T1: no control. Strategy T2: $100 \%$ and $0 \%$ control of the early and late cohorts, respectively. Strategy T3: $75 \%$ and $67 \%$ control of the early and late cohorts, respectively. Strategy T4: 98\% and $100 \%$ control of the early and late cohorts, respectively.

yield (Table 2). Similar results were obtained for other weed species, such as Avena sterilis (GonzalezAndujar and Fernandez-Quintanilla, 1993) or Papaver rhoeas L. (Torra et al., 2008). In the model, first cohort parameters were more sensitive than second cohort parameters (Table 1). Consequently, future research should address novel strategies aimed at increasing the negative impact of these treatment strategies on the infestation ability of the weed.

The poor sensitivity of the model to relevant (40\%) fluctuations in herbicide treatment costs (Table 2), which is important when studying strategies relying on the use of herbicides, should be noted.

On the contrary, if fixed production costs increase by $40 \%$ compared to the baseline value, a major effect on the annualized net returns is projected. This effect is particularly marked for strategy T1 (Table 2).

According to our simulations, two sequential glyphosate applications per year (T4), which aims to control the two cohorts, clearly outperforms all of the alternative strategies because results in lower D. sanguinalis soil seed bank densities and higher soybean yield and economic returns than the alternative strategies. Regarding potential novel strategies to manage this weed, our results suggest that it is important to target both cohorts effectively. This could greatly reduce the number of seeds incorporated into the soil seed bank.

Some authors have shown that the greatest longterm benefit can be achieved by integrating various control options. Thus, this bioeconomic model could be further developed by integrating it within a DSS framework (Gonzalez-Andujar et al., 2010) to help decision-making by both farmers and technicians.

\section{Acknowledgments}

This work was supported in part by FEDER funds and the Spanish Ministry of Innovation and Science (project AGL 2009-7883). We thank the Carolina Foundation for providing a grant to the first author, and we also thank Pilar Castro, Dr. Leguizamon and Dr. Tuesca for their help with this work. 


\section{Resumen}

F.H. Oreja, F. Bastida y J.L. Gonzalez-Andújar. 2012. Simulación de estrategias de control para la toma de decisión de Digitaria sanguinalis en soja resistente a glifosato. Cien. Inv. Agr. 39(2): 299-308. Se desarrolló un modelo bioeconómico para la toma de decisión del control de pasto cuaresma (Digitaria sanguinalis), en el cultivo de soja resistente a glifosato, en la Pampa Ondulada de Argentina. Se evaluaron cuatro estrategias de control de la maleza basadas en el uso de glifosato. En ausencia de herbicida (T1), la población de semillas de la maleza aumenta hasta una densidad de equilibrio de 12.079 semillas $\mathrm{m}^{-2}$. Una única aplicación temprana del herbicida (T2), dirigida a un controlar la primera cohorte de la maleza, permite a la segunda producir la suficiente cantidad de semillas para mantener la densidad poblacional del banco del suelo. Una única aplicación tardía del herbicida (T3), dirigida a controlar la primera y la segunda cohorte, resulta en un aumento del banco de semillas a niveles similares a aquellos alcanzados sin tratamiento. Dos aplicaciones en el mismo año dirigidas a controlar ambas cohortes (T4), llevan al banco de semillas luego de 10 años a sólo un 23,17\% menos que la densidad predicha para el tratamiento sin control. Las predicciones del modelo indican que en ausencia de control, hay un $93 \%$ de pérdida de rendimiento del cultivo a causa de la maleza. La menor reducción del rendimiento del cultivo (27\%) fue predicha con la estrategia T2, el control más común utilizado por los productores locales. Esta estrategia lleva a reducciones en la densidad de semillas en el banco del suelo, a mayores rendimientos del cultivo y retornos económicos comparados con las otras estrategias.

Palabras clave: Análisis de sensibilidad, competencia cultivo-maleza, cultivo transgénico, Digitaria, Glycine max, herbicidas, pasto cuaresma.

\section{References}

Aguyoh, J.N., and J.B. Masiunas. 2003. Interference of large crabgrass (Digitaria sanguinalis) with snap beans. Weed Science 51:171-176.

Bhowmik, P., S. Kushwaha, and S. Mitra. 1999. Response of various weed species and corn (Zea mays) to RPA 201772. Weed Technology 13:504-509.

Buhler, D.D. 1995. The influence of tillage systems on weed populations dynamics and management in corn and soybean in the Central USA. Crop Science 35:1247-1258.

Burnside, O.C., R.G. Wilson, S. Weisberg, and K.G. Hubbard. 1996. Seed longevity of 41 species buried 17 years in Eastern and Western Nebraska. Weed Science 44: 74-86.

Cousens, R., and M. Mortimer. 1995. Dynamics of weed populations. Cambridge University Press, Cambridge. 332 pp.

Culpepper, A.S., A.E. Gimenez, A.C. York, R.B. Batts, and J.W. Wilcut. 2001. Morningglory
(Ipomoea spp.) and Large Crabgrass (Digitaria sanguinalis) control with glyphosate and 2,4-DB mixtures in glyphosate-resistant soybean (Glycine max). Weed Technology 15: 56-61.

Davis, A.S., K.A. Renner, and K.L. Gross. 2005. Weed seed bank and community shifts in a longterm cropping systems experiment. Weed Science 53:296-306.

de la Fuente, E.B., S.A. Suárez, and C.M. Ghersa. 2006. Soybean weed community composition and richness between 1995 and 2003 in the Rolling Pampas (Argentina). Agriculture, Ecosystems \& Environment 115 (1-4): 229-236.

Delouche, J.C. 1956. Dormancy in seeds of Agropyron smithii, Digitaria sanguinalis and Poa pratensis. Iowa State College Journal of Science 30: 348-349.

Egley, G.H., and J.M. Chandler. 1978. Germination and viability of weed seeds after 2.5 years in a 50-year buried seed study. Weed Science 26: 230-239.

Fehr, W.R. and C.E. Caviness. 1977. Stages of soybean development. Special report 80. Iowa State 
University of Science and Technology. Ames. Iowa. $11 \mathrm{pp}$.

Fernandez-Quintanilla, C., L. Navarrete, C. Torner, and J. L. Andujar, 1987. Influence of herbicide treatments on the population-dynamics of $\mathrm{Av}$ ena sterilis ssp ludoviciana (Durieu) Nyman in winter-wheat crops. Weed Research 27: 375-383.

Forcella, F., R.L. Benech Arnold, R. Sanchez, and C.M. Ghersa. 2000. Modelling seedling emergence. Field Crops Research 67:123-139.

Fu, R., and R.A. Ashley. 2006. Interference of large crabgrass (Digitaria sanguinalis), redroot pigweed (Amaranthus retroflexus), and hairy galinsoga (Galinsoga ciliata) with bell pepper. Weed Science 54:364-372.

Gallart, M., A.M.C. Verdú, and M.T. Mas. 2008. Dormancy breaking in Digitaria sanguinalis seeds: the role of the caryopsis covering structures. Seed Science \& Technology 36: 259-270.

Gonzalez-Andujar, J. L., and C. Fernandez-Quintanilla. 1991. Modeling the population dynamics of Avena sterilis under dry-land cereal cropping systems. Journal of Applied Ecology 28:16-27.

Gonzalez-Andujar, J. L., and C. Fernandez-Quintanilla. 1993. Strategies for the control of Avena sterilis in winter wheat production systems in central Spain. Crop Protection 12: 617-623.

Gonzalez-Andujar, J.L., C. Fernandez-Quintanilla, F. Bastida, R. Calvo, L. Gonzalez-Diaz, J. Izquierdo, J.A. Lezaun, F. Perea, M.J. Sanchez del Arco, and J.M. Urbano. 2010. Field evaluation of a decision support system for Avena sterilis ssp. ludoviciana control in winter wheat. Weed Research 50:83-88.

Gonzalez-Díaz, L., F. Bastida, and J.L. GonzálezAndujar. 2009. Modelling of the population dynamics of Phalaris brachystachys Link under various herbicide control scenarios in a Mediterranean climate. Spanish Journal of Agricultural Research 7:35-39.

Hiroyuko, K., and O. Atsushi. 2005. Digitaria ciliaris seedbanks in untilled and tilled soybean fields. Weed Biology and Management 5:53-61.

Holm, L.G., D.L. Plucknett, J.V. Pancho, and J.P. Herberger. 1977. The World's Worst Weeds:
Distribution and Biology. University of Hawaii Press, Honolulu. 609 pp.

James, C. 2001. Global Review of Commercialised Transgenic Crops, 2001. ISAAA Briefs, 24: Preview ISAAA: Ithaca, NY. 15 pp.

King, C.A. and L.R. Oliver. 1994. A model for predicting large crabgrass (Digitaria sanguinalis) emergence as influenced by temperature and water potential. Weed Science 42:561-567.

Leguizamón, E. 1976. Competencia de malas hierbas con soja: efectos sobre el crecimiento y el rendimiento. Actas IV Reunión Técnica Nacional de Soja. Miramar (Buenos Aires). 78 pp.

Marzocca, A. 1994. Guía descriptiva de malezas del cono sur. Instituto Nacional de Tecnología Agropecuaria (INTA). Buenos Aires. 103-104 pp.

Masin, R., M.C. Zuin, S. Otto, and G. Zanin. 2006. Seed longevity and dormancy of four summer annual grass weeds in turf. Weed Research 46:362-370.

Menalled, F.D., P.C. Marino, K.A. Renner, and D.A. Landis. 2000. Post-dispersal weed seed predation in Michigan crop fields as a function of agricultural landscape structure. Agriculture, Ecosystems and Environment 77:193-202.

Mitidieri, A. 1989. El control químico de las malezas en soja Argentina. IV World soybean research conference. Buenos Aires. Argentina. p. 2117-2122.

Molher, C., and B. Callaway. 1995. Effects of tillage and mulch on weed seed production and seed bank in sweet corn. Journal of Applied Ecology 32:627-639.

Monks, D.W., and J.R. Schultheis. 1998. Critical weed-free period for large crabgrass (Digitaria sanguinalis) in transplanted watermelon (Citrullus lanatus). Weed Science 46:530-532.

Norsworthy, J.K. 2004. Soil-applied herbicide use in wide- and narrow-row glyphosate-resistant soybean (Glycine max). Crop Protection 23:12371244.

Oreja, F.H. and E.B. de la Fuente. 2005. Dinámica poblacional del pasto cuaresma (Digitaria sanguinalis (L.) Scop.) en cultivos de soja de la Pampa Ondulada. XVII Congreso de la Asociación Latinoamericana de malezas (ALAM). Varadero, Matanzas, Cuba. p. 767-771. 
Oreja, F.H., and J.L. González-Andújar. 2007. Modelling competition between large crabgrass and glyphosate-resistant soybean in the Rolling Pampas of Argentina. Commun. Biometry Crop Science 2:62-67.

Puricelli, E., and D. Tuesca. 2005. Weed density and diversity under glyphosate-resistant crop sequences. Crop Protection 24: 533-542.

Rahman, A., T.K. James, and N. Grbavac. 2001. Potential of weed seedbanks for managing weeds: a review of recent New Zealand research. Weed Biology and Management 1: 89-95.

Richmond, D.S., P.S. Grewal, and J. Cardina. 2003. Competition between Lolium perenne and Digitaria sanguinalis: Ecological consequences for harbouring an endosymbiotic fungus. Journal of Vegetation Science 14:835-840.

Sarker, M.Y., M. Mossaddeque Hossain, M.K. Hasan, M.A.H. Khan, M.R. Amin, and F. Begum. 2002. Weed infestation in direct seeded and transplanted Australian rice as affected by method of planting and weeding regime. Journal of Biological Science 2:652-655.

Suárez, S.A., E.B. de la Fuente, C.M. Ghersa, and R.J.C. León. 2001. Weed community as an indicator of summer crop yield and site quality. Agronomy Journal 93:524-530.
Swinton, S.M., and R.P. King. 1994. A bioeconomic model for weed management in corn and soybean. Agricultural Systems 44:313-335.

Toole, E.H., and V.K. Toole. 1941. Progress of germination of seed of Digitaria as influenced by germination temperature and other factors. Journal of agricultural research 63: 65-90.

Torra, J., J.L. Gonzalez-Andujar, and J. Recasens. 2008. Modelling the long term population dynamics of poppy (Papaver rhoeas) under various weed management systems. Weed Research 48:136-146.

Tuesca, D., E. Puricelli, and J.C. Papa. 2001. A longterm study of weed flora shifts in different tillage systems. Weed Research 4:369-382.

Van Gessel, M.J., A.O. Ayeni, and B.A. Majek. 2001. Glyphosate in full-season in no-till glyphosate-resistant soybean: role of pre-plant applications and residual herbicides. Weed Technology 15:714-724.

Walker, R. H., G. Wehtje, and J.S. Richburg. 1998. Interference and control of large crabgrass (Digitaria sanguinalis) and Southern Sandbur (Cenchrus echinatus) in forage bermudagrass (Cynodon dactylon). Weed Technology 12:707-711.

Zanin, G., S. Otto, L. Riello, and M. Borin. 1997. Ecological interpretation of weed flora dynamics under different tillage systems. Agricultural, Ecosystems and Environment 66:177-188. 